\title{
NOTE
}

\section{Induction of nitric oxide synthase in channel catfish Ictalurus punctatus by Edwardsiella ictaluri}

\author{
W. Peter Schoor ${ }^{1}$, John A. Plumb ${ }^{2}$ \\ ${ }^{1}$ Environmental Research Laboratory, U.S. Environmental Protection Agency, 1 Sabine Drive, Gulf Breeze, Florida 32561, USA \\ ${ }^{2}$ Department of Fisheries and Allied Aquacultures, Alabama Agricultural Experiment Station, Auburn University, Auburn, Alabama 36849, USA
}

ABSTRACT: Channel catfish Ictalurus punctatus were injected intraperitoneally with live cells of Edwardsiella ictaluri and held in flow-through tanks for $5 \mathrm{~d}$. The head kidneys from injected and control fish were removed and the nitric oxide synthase activity measured. Activities found were $0.16 \pm$ $0.05 \mathrm{nmol}$ L-citrulline formed $\mathrm{mg}^{-1}$ protein $\mathrm{min}^{-1}$ for the injected fish, and $0.002 \mathrm{nmol} \mathrm{mg}^{-1} \mathrm{~min}^{-1}$ for the control fish.

KEY WORDS: Nitric oxide synthase Channel catfish Edwardsiella ictaluri

Enteric septicemia in catfish caused by Edwardsiella ictaluri (Hawke et al. 1981) has been described as the most serious infectious disease to affect the catfish industry in the United States (Vinitnantharat \& Plumb 1993). Based on recent findings that nitric oxide is involved in septic shock (Moncada et al. 1991, Lancaster 1992), and is inducible in macrophages (Stuehr \& Marletta 1985), attempts were made to document the induction of nitric oxide synthase (NOS) in the head kidney of channel catfish Ictalurus punctatus by the enterobacterium. The choice of this tissue reflects the fact that it contains large numbers of macrophages.

Two types of nitric oxide synthase have been shown to exist in mammals, a constitutive type involved in signal transmission (Ignarro 1991) and an inducible type involved in cellular defense (Moncada et al. 1991). Of the 2 types, only the constitutive form has been found in other than mammalian species. It was demonstrated by immunochemical techniques in neurons of the intestinal tract of the toad Bufo marinus using rabbit antibody against purified rat cerebellum NOS (Li et al. 1992).

Methods. Nine channel catfish, ranging from 420 to $560 \mathrm{~g}$ weight, were used in the experiment. Six fish were injected each with $3 \times 10^{6}$ colony-forming Edwardsiella ictaluri in $1 \mathrm{ml}$ of sterile saline solution. Three fish served as controls, and were not shaminjected. The head kidneys from 3 exposed catfish were pooled (Fish 1 to 3 ); the others were analyzed individually (Fish 4, 5 and 6). Tissues from the control catfish were pooled. The head kidneys were removed $5 \mathrm{~d}$ after the injection (approximately $0.5 \mathrm{~g}$ tissue per fish) and homogenized in a glass grinder at a $3: 1$ ratio $(\mathrm{w} / \mathrm{v})$ with a buffer containing $40 \mathrm{mM}$ Tris ( $\mathrm{pH} 7.9$ ), $0.25 \mathrm{M}$ glucose, $0.1 \mathrm{mM}$ phenylmethylsulfonylfluoride, $3 \mathrm{mM}$ dithiothreitol, $4 \mu \mathrm{M}$ flavine adenine dinucleotide (FAD), $5 \mathrm{mM} \mathrm{L}$-arginine, $5 \mu \mathrm{g} \mathrm{ml}^{-1}$ aprotinin, $5 \mu \mathrm{g} \mathrm{ml}^{-1}$ pepstatin $A$, and $1 \mu \mathrm{g} \mathrm{ml}^{-1}$ chymostatin (Stuehr et al. 1991). The homogenate was centrifuged at $100000 \times g$ for $90 \mathrm{~min}$ at $4^{\circ} \mathrm{C}$ and the supernate concentrated and washed by ultrafiltration using a $10000 \mathrm{MW}$ cut-off membrane with the same buffer, but lacking glucose and L-arginine. The supernate was frozen at $-80^{\circ} \mathrm{C}$.

The NOS activities were determined in a buffer containing $40 \mathrm{mM}$ HEPES [N-(2-hydroxyethyl)piperazine$\mathrm{N}^{\prime}$-(2-ethanesulfonic acid)] $(\mathrm{pH}$ 7.9), $1 \mathrm{mM}$ nicotinamide adenine dinucleotide phosphate (reduced form) (NADPH), $1 \mathrm{mM}$ dithiothreitol, $1 \mathrm{mM}$ L-arginine, $0.1 \mathrm{mM}$ tetrahydrobiopterin, $1 \mu \mathrm{M}$ FAD, and 10 to $25 \mu \mathrm{l}$ of enzyme in a total volume of $0.6 \mathrm{ml}$, incubated at $37^{\circ} \mathrm{C}$ (Stuehr et al. 1991). Aliquots of $100 \mu$ l were taken at various times and reacted with $5 \mu$ l of a pre-column derivatization mixture containing $10 \mathrm{mg}$ o-phthalaldehyde, $25 \mu \mathrm{l} \beta$-mercaptoethanol, and $0.5 \mathrm{ml}$ buffer containg $0.4 \mathrm{M}$ borate, $7 \mathrm{mM}$ EDTA (ethylenediaminetetraacetic acid), and $0.1 \%$ Brij-35, pH 9.4. The mixture was allowed to react for 2 min in the dark before being chromatographed on a C-18 HPLC (high performance liquid chromatography) column. Elution 
Table 1. Comparison of nitric oxide synthase activities from various sources

\begin{tabular}{|c|c|c|c|}
\hline Enzyme source & Enzyme type & $\begin{array}{c}\text { Activity } \\
\left.\text { (nmol mg }{ }^{-1} \mathrm{~min}^{-1}\right)\end{array}$ & Reference \\
\hline Rat cerebellum & Constitutive & $0.16 \quad(960)$ & Bredt \& Snyder (1990) \\
\hline Bovine cerebrum & Constitutive & $0.074 \quad(350)$ & Ohshima et al. (1992) \\
\hline Rat peritoneal neutrophils & Induced & $0.93 \quad(122\}$ & Yui et al. (1991a) \\
\hline Mouse peritoneal macrophages & Induced (LPS) & $2.5 \quad(1060)$ & Stuehr et al. (1991) \\
\hline Rat peritoneal macrophages & Induced (LPS) & $2.1 \quad(944)$ & Yui et al. (1991b) \\
\hline Rat liver & Induced (LPS) & $(223)$ & Evans et al. (1992) \\
\hline
\end{tabular}

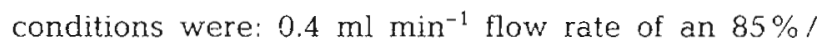
$15 \%$ mixture of $50 \mathrm{mM}$ sodium acetate $/ 4 \%$ acetonitrile, $\mathrm{pH} 5.85$, and of $75 \% / 25 \%$ acetonitrile/methanol. The fluorescence was measured at $254 \mathrm{~nm}$ and compared to that of L-arginine and L-citrulline standards. The enzymatic activity, determined from the linear portion of the activity curve, was expressed in nmol Lcitrulline produced $\mathrm{mg}^{-1}$ protein $\mathrm{min}^{-1}$. The lowest level of activity detectable under the above conditions was $1 \mathrm{pmol} \mathrm{mg}^{-1} \mathrm{~min}^{-1}$.

An LPS- (lipopolysaccharide-) induced murine peritoneal macrophage NOS preparation was used as the methodology standard; it exhibited an activity of

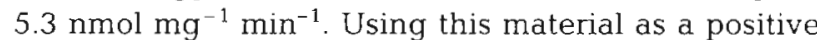
control, the assay procedure for NOS listed above showed a reproducibility of $\pm 5 \%$.

Results and discussion. Using the method described above for the determination of NOS activity, the following values were obtained:

\section{$0.15 \mathrm{nmol} \mathrm{mg}^{-1} \mathrm{~min}^{-1}$}

$0.16 \pm 0.05 \mathrm{nmol} \mathrm{mg}^{-1} \mathrm{~min}^{-1}$

$0.002 \mathrm{nmol} \mathrm{mg}^{-1} \mathrm{~min}^{-1}$

Because this work reports the first NOS activity measured in a fish species, the NOS values in Table 1 are provided for comparison. It is noted that these studies used different starting materials as well as different methods for measuring NOS activity. Additional, preliminary information on the occurrence of NOS in fishes obtained from chinook salmon Oncorhynchus tshawytscha with natural (clinically evident) bacterial kidney disease showed an activity of approximately 2 nmol citrulline formed $\mathrm{mg}^{-1}$ protein $\mathrm{min}^{-1}$ in the head kidney; the analogous NOS value for clinically normal but possibly infected chinook salmon was
2 -fold lower In the light of this information it is highly unlikely that handling the exposed catfish caused an increase in the observed NOS activity.

The NOS activity observed in the control catfish head kidneys, while very low, has been observed in peritoneal macrophages from healthy mice (Palacios et al. 1992). Knowles et al. (1990) also found background activity in control rat liver, but not rat lung tissue. The significance of this is not clear, but in the absence of the constitutive enzyme, might reflect some sub-effects level.

Conclusion. We report an approximately 80 -fold increase in the NOS activity in channel catfish after treatment with Edwardsiella ictaluri, the first such activity to be measured in a fish species, and suggest that this occurred in direct response to the treatment. We infer from the data that the model developed for the involvement of NOS in septic shock in mammalian species also applies to fish species. Future information. on a possible dose-response relationship in fish will aid greatly in evaluating the use of NOS data for indicating exposure to natural pathogens and/or their toxins.

Acknowledgements. W.P.S. gratefully acknowledges receiving the mouse macrophage homogenate from Dr Dennis $J$. Stuehr, Cleveland Clinic Foundation, and the chinook salmon samples from Dr Michael Kent, Fisheries and Oceans, Canada. Also acknowledged are the helpful discussions with John A. Couch of the Environmental Research Laboratory, Gulf Breeze.

\section{LITERATURE CITED}

Bredt, D. S., Snyder, S. H. (1990). Isolation of nitric oxide synthase, a calmodulin-requiring enzyme. Proc. natl Acad. Sci. U.S.A. 87: $682-685$

Evans, T., Carpenter, A., Siva, A., Cohen, J. (1992). Differential effects of monoclonal antibodies to tumor necrosis factor alpha and gamma interferon on induction of hepatic nitric oxide synthase in experimental gramnegative sepsis. Infect. Immun. 60(10): 4133-4139

Hawke, J. P., McWhorter, A. C., Steigerwalt, A. G., Brenner, D. J. (1981). Edwardsiella ictaluri sp. nov., the causative 
agent of enteric septicemia of catfish. Int. J. syst. Bacteriol. 31: $396-400$

Ignarro, L. J. (1991). Signal transduction mechanisms involving nitric oxide. Biochem. Pharmacol. 41(4): 485-490

Knowles, R. G., Marrett, M. Salter, M., Mocada, S. (1990) Differential induction of brain, lung and liver nitric oxide synthase by endotoxin in the rat. Biochem. J. 270:833-836

Lancaster, J. R. Jr (1992). Nitric oxide in cells. Am. Sci. 80: $248-259$

Li, Z. S., Furness, J. B., Young, H. M., Campbell, G. (1992). Nitric oxide synthase immunoactivity and NADPH diaphorase enzyme activity in neurons of the gastrointestinal tract of the toad, Bufo marinus. Arch. Histol Cytol. $55(4): 333-350$

Moncada, S., Palmer, R. M. J., Higgs E. A. (1991). Nitric oxide: physiology, pathophysiology, and pharmacology. Pharmacol. Rev. 43(2): 109-141

Ohshima, H., Oguchi, S., Adachi, H., Iida, S., Suzuki, H., Sugimura, T., Esumi, H. (1992). Purification of nitric oxide synthase from bovine brain: immunological characterization and tissue distribution. Biochem. Biophys. Res. Commun. 183(1): 238-244

Palacios, M., Knowles, R. G., Moncada, S. (1992). Enhancers

Responsible Subject Editor: T. Evelyn, Nanaimo, B.C., Canada of nonspecific immunity induce nitric oxide synthase: induction does not correlate with toxicity or adjuvancy. Eur. J. Immunol. 22: 2303-2307

Stuehr, D. J., Cho, H. J., Kwon, N. S., Weise M. F., Nathan, C. F. (1991). Purification and characterization of the cytokine-induced macrophage nitric oxide synthase: an FAD- and FMN-containing flavoprotein. Proc. natl Acad. Sci. U.S.A. 88: $7773-7777$

Stuehr, D. J., Marletta, M. A. (1985). Mammalian nitrate biosynthesis: mouse macrophages produce nitrite and nitrate in response to Escherichia coli lipopolysaccharide. Proc. natl Acad. Sci. U.S.A. 82: 7738-7742

Vinitnantharat, S., Plumb, J. A. (1993). Pratection of channel catfish Ictalurus punctatus following natural exposure to Edwardsiella ictaluri and effects of feeding antigen on antibody titer. Dis. aquat. Org. 15: 31-34

Yui, Y., Hattori, R., Kosuga, K., Eizawa, H., Hiki, K., Ohkawa, S., Ohnishi, K., Terao, S., Kawai, C. (1991a). Calmodulinindependent nitric oxide synthase from rat polymorphonuclear neutrophils. J. biol. Chem. 266(6): 3369-3371

Yui, Y., Hattori, R, Kosuga, K., Eizawa, H., Hiki, K., Kawai, C. (1991b). Purification of nitric oxide synthase from rat macrophages. J. biol. Chem. 266(19): 12544-12547

Manuscript first received: October 26, 1993

Revised version accepted: March 16, 1994 